Heinesen, M. 1987: Nedre tertiære basaltbreccier og undervands-lavastrømme, sydlige Disko, Vestgrønland: Strukturelle, petrografiske og mineralogiske studier. Unpublished cand. scient. thesis. Københavns Universitet.

Koch, B. E. 1959: Contribution to the stratigraphy of the non-marine Tertiary deposits on the south coast of the Nûgssuaq Peninsula, northwest Greenland. Bull. Grønlands geol. Unders. 22 (also Meddr Grønland 162,1) 100 pp.

Larsen, L. M. \& Pedersen, A. K. 1988: Investigations of
Tertiary volcanic rocks along the south coast of Nûgssuaq and in eastern Disko, 1987. Rapp. Grønlands geol. Unders. 140 (this report).

Pedersen, A. K. 1985: Lithostratigraphy of the Tertiary Vaigat Formation on Disko, central West Greenland. Rapp. Grønlands geol. Unders. 124, $30 \mathrm{pp}$.

Pedersen, A. K. \& Larsen, L. M. 1987: Early Tertiary volcanic rocks from eastern Disko and south-eastern Nûgssuaq. Rapp. Grønlands. geol. Unders. 135, 11-17.
K. S. D.,

Institut for Landmàling og Fotogrammetri,

Danmarks Tekniske Højskole,

Landmälervej 7 ,

DK-2800 Lyngby,

Denmark.
A. K. P.,

Geologisk Museum, $\emptyset$ ster Voldgade 5-7, $D K-1350$ Copenhagen $K$, Denmark.

\title{
Examples of bar accretion in fluvial sand, the Atane Formation, eastern Disko, West Greenland
}

\author{
Gunver Krarup Pedersen and Morten Willaing Jeppesen
}

The aim of the present paper is to supply additional sedimentological observations and to add new details to the existing interpretation of the Atane Formation on eastern Disko. Examples of epsilon cross-bedding reflect formation of point bars and indicate intermittent development of sinuous channels in the coarse-grained braided river. Large tabular sets of planar cross-bedding are interpreted as transverse bars and the coalescence of two such bars are discussed in detail. The field work was carried out during five days in July 1987 as part of a sedimentological research project supported by GGU and financed by SNF.

\section{Background}

White to pale yellow, slightly consolidated sand is widely exposed on eastern Disko below the Tertiary volcanic rocks. The sand was deposited in $10-40 \mathrm{~m}$ thick sequences capped by relatively thin clay horizons and eventually by coal seams. Palaeobotanical studies of these indicate a late Cretaceous age (Miner, 1932) and the sand is referred to the Atane Formation (Henderson et al., 1976).

Johannessen \& Nielsen (1982) and Bennike et al. (1981) studied the Atane Formation at Pingo and Skansen (fig. 1) and suggested deposition by a sandy braided river. They based their interpretation on the predominance of current-generated sedimentary structures, the unimodal palaeocurrents and the lack of channel abandonment or classical, fining-upwards point bar sequences characteristic of meandering rivers. The

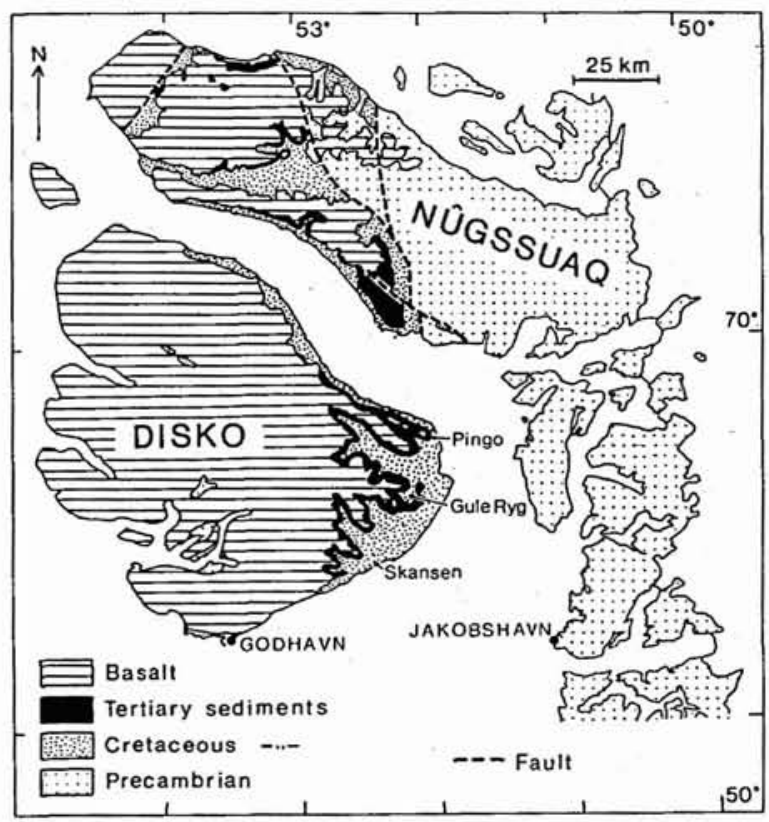

Fig. 1. Location map, showing the distribution of the Cretaceous sediments in the Nûgssuaq Embayment and the localities where the fluvial sediments have been studied. 
Fig. 2. A brief summary of the sedimentary facies of the Gule Ryg area accompanied by two vertical logs measured through exposures adjacent to those of figs 4 and 6 . The lithofacies denominations of Miall (1977) have been used.

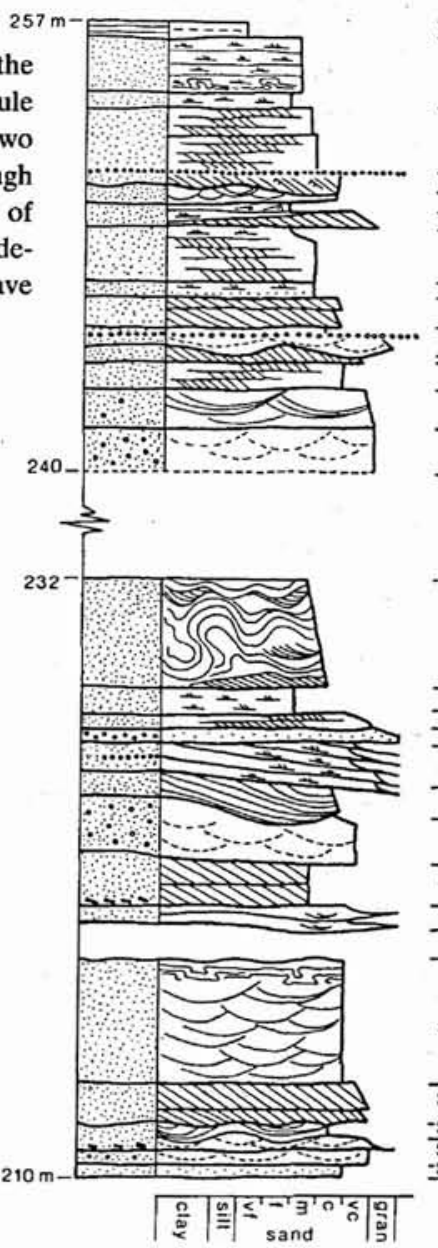

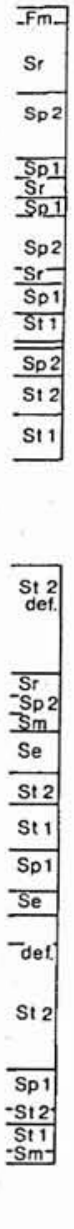

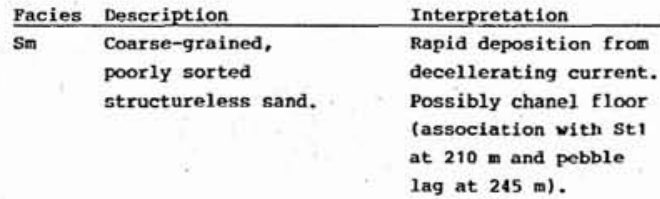

St 1 Medium- to coarse-grained, locally pebbly sand with indistinct cross strata. Troughs are 10-20 cm deep and op Dunes migrating within to $100 \mathrm{~cm}$ wide.

St 2 Medium-grained sand with distinct cross strata. Troughs are generall $8-10 \mathrm{~cm}$ deep and $30-50 \mathrm{~cm}$ wide.

Sp 1 Solitary sets of planar tabular cross strata, often 50-150 cm thick. Facies 1, see text.

Medium- to very coarse-grained sand with tabular angular cross strata. Individual beds are $10-40 \mathrm{~cm}$ thick and form cosets up to 5-6 $\mathrm{m}$ thick.

\section{Se Epsilon cross} stratification. Facies 3, see text. Sr Cross Iaminated fineto medium-grained sand, current generated structures.

s def Soft sediment deformation ranging from oversteepened foresets to intricate slump folds. channels or superimposed on bars or sandflats (Miall, 1977; Cant \& Walker, 1976).

Transverse bar

Trains of straight crested sandwaves migrating across sandflats (Johannesen s Nielsen, 1982). Point bar.

Low energy subenvir.. slough channels, top of sand flat, lower point bar. Deformation of liquefied sedinent caused by water escape (P1int, 1983). palaeogeography of the northward flowing river is illustrated by Surlyk (1982).

Miall $(1977,1978)$ grouped braided rivers into six types of which the Platte type is characterized by an abundance of linguoid (transverse) bar and dune deposits, lack of well-developed cyclicity, and by a predominance of sand-sized sediment. The South Saskatchewan type is dominated by trough cross-bedded sand and characterized by thinning- and fining-upward cyclic sequences. Conceptual models of the distribution of bedforms and macroforms within these two types of rivers are illustrated as models 9 and 10 by Miall (1985). One or both of these models may encompass the Cretaceous sand of the Gule Ryg area.

\section{Observations}

Our observations show that vertical sequences are highly variable and fining-upward trends are weak and generally restricted to the upper $2-3 \mathrm{~m}$ below laterally persistent beds of silt, shale and thin coal seams (fig. 2). These horizons of fine-grained sediments delineate stages in vertical accretion of the fluvial system and range as third order bounding surfaces in the classification of Allen (1983) and Miall (1985). The sedimentary facies described by Johannessen \& Nielsen (1982) are all recognized at Gule Ryg but occur in different proportions. A summary of the sedimentary facies is given in fig. 2, and only the transverse bar (facies 1 and 2) and the point bar (facies 3 and 4) are described below in greater detail and illustrated in figs $3,4,5$ and 6.

\section{Transverse bar}

Facies 1: transverse bar front (figs 3, 4). Facies 1 comprises solitary tabular sets, (D) and (F), of large-scale cross-bedded, medium-grained sand with planar, tangential foresets. The foreset laminae are 1-2 cm thick, normally graded up-dip, while grading across individual foresets is insignificant. Large variations in grain size 


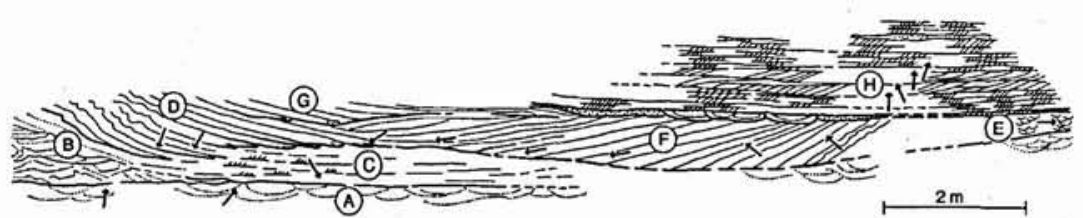

$\begin{array}{ll}\text { Large scale trough cross strata } & \text { Palaeocurrent } \\
\text { Ledium -. } & \text { Depositional unit } \\
\text { Plange scale planar tabular } & \text { Pebbly sand }\end{array}$
Fig. 3. Section through two transverse bars. Note the systematic change in palaeocurrent directions in $\mathrm{F}$ which indicate that the front of the bar was lobate. are, however, found between successive foreset laminae. Some of these pinch out halfway down the slip-face and some are lenticular in cross section similar to the subaqueous grain flows discussed by Hunter (1985). The down-dip increase in grain size is especially pronounced in $G$, where the cross strata are seen to have sharp, locally lobate toes, which strongly point to deposition from avalanching. Coal debris is locally accumulated at the base of foresets. Reactivation surfaces are rare.

Topset strata are neither preserved in $\mathrm{D}$, which is truncated upwards by a Quaternary erosion surface, nor in $\mathrm{F}$ which is cut by small scours and erosively overlain by a thin wedge of pebbly sand succeeded by cosets of tabular cross-bedded sand (fig. 3). Both D and F formed through lateral accretion on a core of trough cross-bedded sand which was an erosional remnant of slightly older deposits. Adjacent to the cores the foresets are oversteepened and slightly deformed by small slump folds (fig. 4).

Facies 2: bottom sets of the bar (figs 3, 4). Facies 2 comprises parallel-bedded, medium-grained sand with a low angle of dip denoted by C. The beds are $c .5 \mathrm{~cm}$ thick and form the continuation of the foreset laminae of D (fig. 4). Cross laminated intrabeds show ripple migration obliquely towards the slip face of the bar. This cross-lamination was produced by a subordinate current, similar to the low stage flow discussed by Collinson (1970) and Hobday et al. (1981).
Interpretation. Facies 1 is interpreted as avalanche deposition on the slip face of a bedform similar to the transverse, linguoid or cross-channel bars discussed by Collinson (1970), Smith (1971), Cant \& Walker (1978), Miall (1977), Hobday et al. (1981). The systematic change in foreset orientation, indicating palaeocurrents from $310^{\circ}$ to $240^{\circ}$ in (F) (fig. 3), indicate that the bar front was lobate.

Figure 3 shows that the two bars $\mathrm{F}$ and $\mathrm{D}$ formed simultaneously. F migrated across the bottom sets $\mathrm{C}$ of $D$, but $F$ was finally overlain by $G$ which succeeded $D$ (figs 3,4). The coexistence of two bars support the interpretation of the bar front of $\mathrm{F}$ as lobate, because linguoid transverse bars are reported to occur in large fields in recent rivers (Collinson, 1970, Blodgett \& Stanley, 1980).

The scarcity of reactivation surfaces may indicate that the discharge was relatively stable or that the bedform migrated more rapidly than fluctuations in discharge occurred. Oversteepened foresets and the small-scale slump deformations are compatible with rapid deposition during high-flow stage (Plint, 1983).

Reactivation surfaces were, however, generated where one transverse bar was overtaken by its successor (Johannessen \& Nielsen, 1982, fig. 13e, f). Repetitive reactivation surfaces of this type were also seen at Gule Ryg, but appear here to be restricted to smaller bars (slip faces $50-60 \mathrm{~cm}$ high). A similar pattern of reactivation surfaces is described from mid-channel bars by Haszeldine (1983).

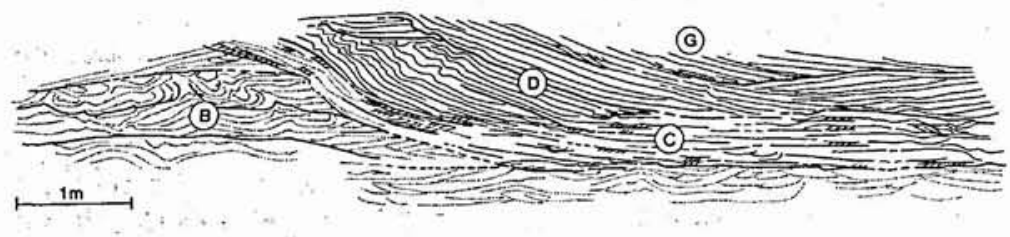

Fig. 4. Details of fig. 3 showing slip face strata $D$, bar bottomsets $\mathrm{C}$ and a core of older sediment $\mathrm{B}$. The trough cross-bedding of $\mathrm{B}$ was distorted through water escape liquefaction prior to deposition of D. The foreset strata of D are oversteepened adjacent to B indicating continued plastic deformation. Same signature as fig. 3. 


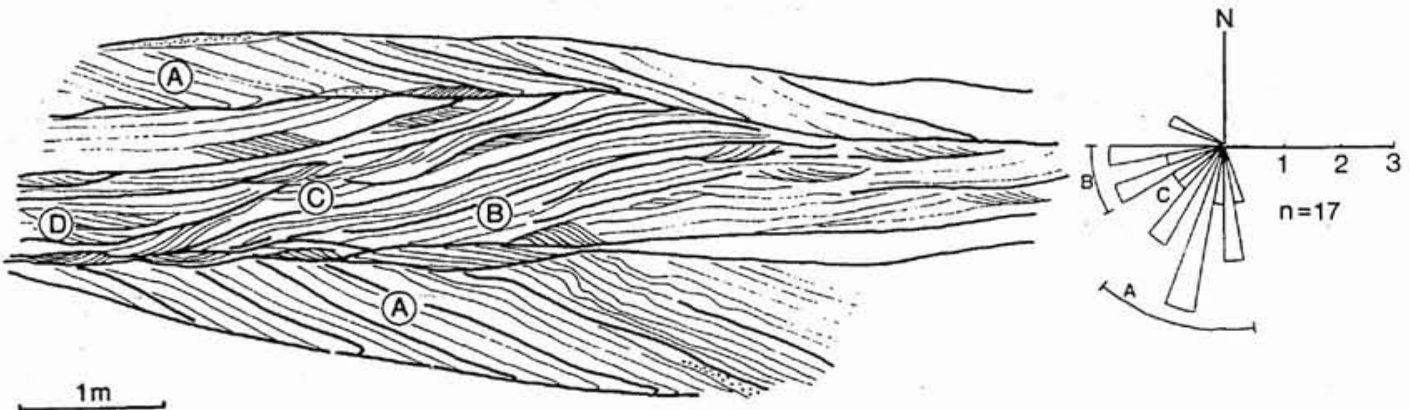

Fig. 5. Point bar intercalated between two transverse bars. A: transverse bars. B: epsilon cross-bedding. C: proximal part of facies 4. D: distal part of facies 4. Palaeocurrents of the depositional units are plotted for comparison.

Hobday et al. (1981) reported small scour channels on top of transverse bars and interpreted them as low stage dissection during partial emergence of the bar. Similar scours are seen in F (fig. 3) and in fig. 5.

Both bars are seen to have evolved through lateral accretion on cores of slightly older, trough cross-bedded sand (facies St2, units B and E, fig. 3). This supports the interpretation (Johannessen \& Nielsen, 1982) of the river as characterized by frequent shifts between flooded or partially emergent bedforms.

\section{Point bar}

Facies 3: epsilon cross-bedding (figs 5, 6). Facies 3 consists of large-scale, gently dipping, planar cross-bedded, medium- to coarse-grained sand. The foreset laminae are $2-5 \mathrm{~cm}$ thick and normally graded across. Coal clasts of $1 \mathrm{~cm}$ are accumulated in the bottomsets. The unit contains several reactivation surfaces separating 15-20 $\mathrm{cm}$ thick bundles of foresets. The upper terminations of the foresets show offlap, while their lower terminations downlap on the channel floor or interfinger with facies 4. The top of the foresets dip $c .15^{\circ}$ while the tangential bottom sets grade laterally into facies 4 . In the upper part some small scour channels are seen.

Facies 3 is interpreted as epsilon cross-bedding. The lateral transition of facies 3 into facies 4 suggests a morphology like the lower point bar of McGowen \&
Garner (1970: fig. 4), though without associated chute bars. The properties of facies 3 are also comparable to those of the lateral accretion element or epsilon crossbedding proposed by Miall (1985).

Facies 4: cross-lamination of lower point bar (figs 5, 6). The second depositional unit is built up by subhorizontal, 5-10 cm thick sets of cross-laminated mediumgrained sand. The distal parts are comparable to the trough fill and foreset cross-stratification of McGowen \& Garner (1970). In the proximal parts the sets become steeper, while the intrasets show ripple migration across the foresets of facies 3. Parallel laminae of sand are interbedded with the cross-laminated sand and drape the whole structure (fig. 5). The transitional zone between facies 3 and 4 is characterized by contortion of the cross-bedding and obliteration of all the internal small-scale structures. This feature is possibly related to liquefaction during the rapid deposition (Levey, 1978). Facies 4 was probably deposited in a lower point bar environment similar to the deposition at low stage flow conditions in the Amite and Colorado rivers (McGowen \& Garner, 1970).

Interpretation. The point bars are thought to have formed under relatively quiet flow conditions in a 'secondary meandering river' between the emergent sand flats in the braided river system.

Fig. 6. Point bar complex showing that the lateral sequence from facies 3 to 4 shown in fig. 5 is repeated.

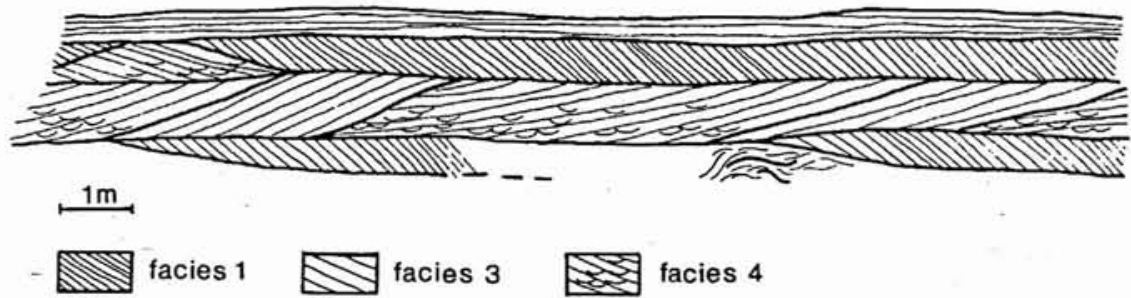




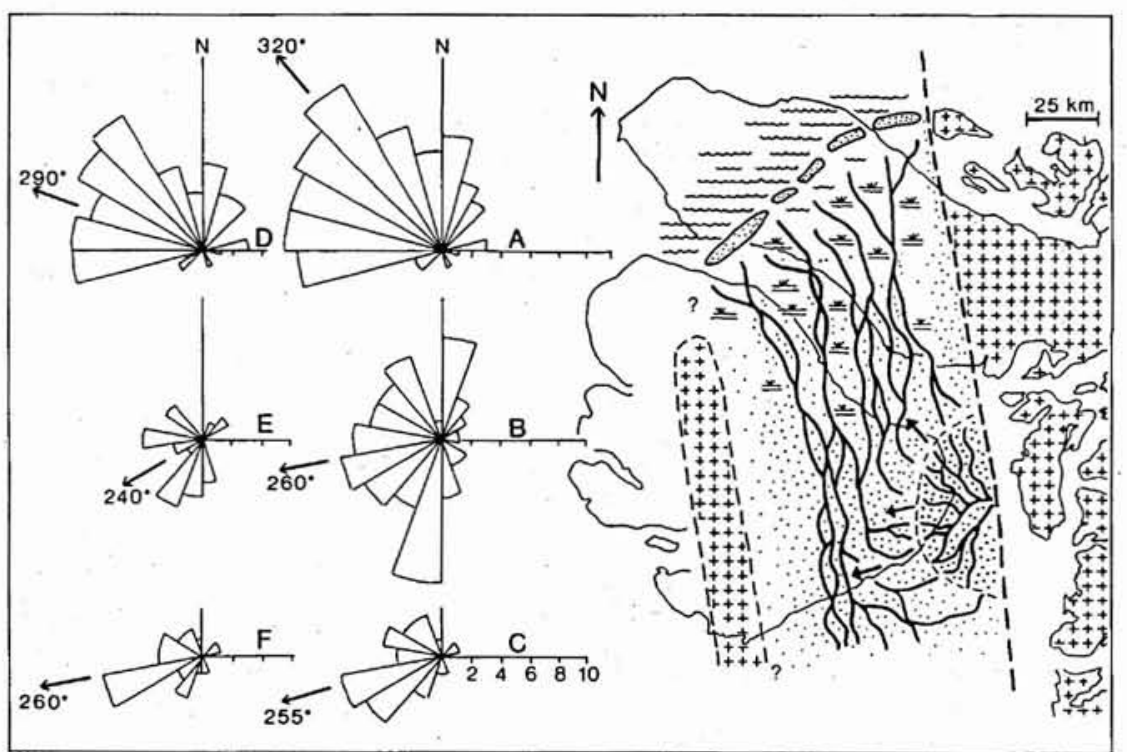

Fig. 7. Palaeogeographical sketch of the Nûgssuaq Embayment during deposition of the Atane Formation. Modified from Surlyk (1982). Palaeocurrent directions at Pingo, Gule Ryg and Skansen suggest sediment influx via an alluvial fan adjacent to the fault which borders the basin. Diagrams A, B, C include the total number of measurements, while D, E, F illustrate orientation of slip faces of facies 1 . Diagrams A, C, D, F are redrawn from Bennike et al. (1981) and Johannessen \& Nielsen (1982). A: $\mathbf{n}=$ $100, B: n=73, C: n=34, D: n=$ $79, \mathrm{E}: \mathrm{n}=25, \mathrm{~F}: \mathrm{n}=27$.
Figure 6 illustrates repetition of the lateral sequence composed of facies 3 and 4 . The cyclic development of the point bar reflects varying discharge within this lower flood stage. Epsilon cross-strata represent maximum discharge and the cross-laminated and parallel laminated sand formed during minimum discharge conditions.

\section{Discussion}

The presence of epsilon cross-bedding associated with cross-lamination indicate deposition on point bars. Classical point bar sequences (Allen, 1970) with pronounced fining-upward trends and capped by overbank mud and coal are, however, lacking. Neither are channel abandonment sequences found. Point bar development was therefore presumably restricted to shorter periods of low-flow stage when sinuous channels developed between emergent sand flats. These may have been vegetated as comminuted plant debris is ubiquitous.

Transverse bars are seen in association with sand flat or point bar facies in figs 3 and 6 . The former association corresponds to the facies model of the South Saskatchewan River (Cant \& Walker, 1978). This model illustrates further the importance of channel floor deposition (facies St) which has occurred frequently in the sequence shown in fig. 2 . The fluvial deposits in the Gule Ryg area do, however, have less pronounced fining-upward trends and less fine-grained sediment than has the South Saskatchewan model. Thin shale layers locally associated with thin coal seams are laterally continuous over hundreds of metres at Gule Ryg and divide the formation into $10-40 \mathrm{~m}$ thick sequences. Johannessen \& Nielsen (1982) found that transverse bars predominate in the Pingo area and that signs of exposure are rare. They therefore concluded that the bars migrated in a wide, shallow river which only developed a braided channel pattern during low-flow stage.

\section{Palaeocurrents}

Palaeocurrent data from facies $1-4$ are shown in detail in figs 3 and 5, and are included in fig. 7. The large spread in current directions is noteworthy, as is the lack of easterly directions. Most measurements were made of foreset orientations, and variations are found both between and within facies. This wide range of local flow directions indicates that the river was a multichannel system at least during low-water stages where the flow was channelled between metastable bars and sand flats.

The regional distribution of sedimentary facies within the Cretaceous of the Nûgssuaq Embayment shows fluvial sand on eastern Disko, delta-plain sand-shale-coal in southern Nûgssuaq and marine shales in northern Nûgssuaq. The main sediment transport was therefore towards the north as shown by Surlyk (1982).

Johannessen \& Nielsen (1982) found unimodal palaeocurrents towards the north-west at Pingo while south-westerly directions predominate at Skansen (Bennike et al., 1981). The current data from Gule Ryg are thus intermediate and all three current-roses are plotted for comparison in fig. 7. The many westerly current directions could reflect sediment transport into the Nûgssuaq Embayment via an alluvial fan adjacent to the 
regional fault which now separates this basin from the Precambrian terrain to the east.

\section{Conclusion}

Our observations support the existing interpretation of the Atane Formation on eastern Disko as a sandy braided river (Bennike et al., 1981; Johannessen \& Nielsen, 1982; Surlyk, 1982). The recognition of point bar sequences indicates the establishment of sinuous channels during low-flow stage. The palaeocurrents show a variety of directions, most with a westerly component. Compared with palaeocurrent directions from Pingo and Skansen this suggests sediment transport into the Nûgssuaq Embayment via alluvial fans along the eastern margin of the basin.

Acknowledgements. The field work was financed through a grant, j.nr. 11-6350, from the Danish Natural Science Research Council. Support from Arktisk Station, University of Copenhagen, and from GGU is also gratefully acknowledged.

\section{References}

Allen, J. R. L. 1970: Studies in fluviatile sedimentation: a comparison of fining-upward cyclothems with special reference to coarse-member composition and interpretation. $J$. Sediment.Petrol. 40, 298-323.

Allen, J. R. L. 1983: Studies in fluviatile sedimentation: bars, bar-complexes and sandstone sheets (low sinuosity braided streams) in the Brownstones (L. Devonian), Welsh Borders. Sediment. Geol. 3, 237-293.

Bennike, O., Boserup, M., Brüsch, W., Hegner, J., Johannessen, P., Nielsen, L. H. \& Vejbæk, O. 1981: Skansen. In: Rapport fra geologisk feltkursus ved Arktisk Station 1981. Geologisk Centralinstitut, 58-66. Univ. Copenhagen.

Blodgett, R. H. \& Stanley, K. O. 1980: Stratification, bedforms, and discharge relations of the Platte braided river system, Nebraska. J. Sediment. Petrol. 50, 139-148.

Cant, D. J. \& Walker, R. G. 1978: Fluvial processes and facies sequences in the sandy braided South Saskatchewan River, Canada. Sedimentology 25, 625-648.

Collinson, J. D. 1970: Bedforms of the Tana River, Norway. Geogr. Annls 52-A, 31-56.

Haszeldine, R. S. 1983: Descending tabular cross-bed sets and bounding surfaces from a fluvial channel in the Upper Carboniferous coalfield of north-east England. Spec. Publs int. Ass. Sediment. 6, 449-456.
Henderson, G., Rosenkrantz, A. \& Schiener, E. J. 1976: Cretaceous-Tertiary sedimentary rocks of West Greenland. In Escher, A. \& Watt, W. S. (edit.) Geology of Greenland, 341-362. Copenhagen: Geol. Surv. Greenland.

Hobday, D. K., Woodruff, jr. C. M. \& McBride, M. W. 1981: Paleotopographic and structural controls on non-marine sedimentation of the Lower Cretaceous Antlers Formation and correlatives, North Texas and southeastern Oklahoma. Spec. Publ. Soc. Econ. Paleont. Miner. 31, 71-87.

Hunter, R. E. 1985: Subaqueous sand-flow cross strata. $J$. Sediment. Petrol. 55, 886-894.

Johannessen, P. N. \& Nielsen, L. H. 1982: Aflejringer fra flettede floder, Atane Formationen, Øvre Kridt, Pingo, øst Disko. Arsskr. dansk geol. Foren. 1981, 13-27.

Levey, R. A. 1978: Bed-form distribution and internal stratification of coarse-grained point bars, Upper Congaree River, S.C. In Miall, A. D. (edit.) Fluvial sedimentology. Mem. Can. Soc. Petrol. Geol. 5, 105-127.

McGowen, J. H. \& Garner, L. E. 1970: Physiographic feature and stratification types of coarse-grained point bars: modern and ancient examples. Sedimentology 14, 77-111.

Miall, A. D. 1977: A review of the braided-river depositional environment. Earth-Sci. Rev. 13, 1-62.

Miall, A. D. 1978: Lithofacies types and vertical profile models in braided river deposits: a summary. In Miall, A. D. (edit.) Fluvial sedimentology. Mem. Can. Soc. Petrol. Geol. 5, 597-604.

Miall, A. D. 1985: Architectural-element analysis: a new method of facies analysis applied to fluvial deposits. EarthSci. Rev. 22, 261-308.

Miner, E. L. 1932: Megaspores ascribed to Selaginellites from the Upper Cretaceous coals of western Greenland. J. Wash. Acad. Sci. 22, 497-505.

Plint, A. G. 1983: Sandy fluvial point-bar sediments from the Middle Eocene of Dorset, England. Spec. Publs int. Ass. Sediment. 6, 355-368.

Smith, N. D. 1971: Transverse bars and braiding in the lower Platte River, Nebraska. Bull. geol. Soc. Amer. 82, 34073420.

Surlyk, F. 1982: Kul på Nûgssuaq, Vestgrønland. In Shekhar, S. C., Frandsen, N. \& Thomsen, E. Coal on Nagssuaq, West Greenland, 43-56. Copenhagen: Geol. Surv. Greenland.
Geologisk Centralinstitut, Øster Voldgade 10, DK-1350 Copenhagen $K$, Denmark. 